\title{
Correction to: Improving the performance of dye-sensitized solar cells using nanoparticles and a dye produced by an Antarctic bacterium
}

\author{
Juan José Marizcurrena ${ }^{1} \cdot$ Susana Castro-Sowinski ${ }^{1} \cdot$ María Fernanda Cerdá2 $®$
}

Published online: 1 June 2021

(c) Society for Environmental Sustainability 2021

\section{Correction to: Environmental Sustainability https://doi.org/10.1007/s42398-021-00168-8}

The original version of this article unfortunately contained a mistake. In Fig. 3, the units of the Y-axis were incorrect. The corrected Fig. 3 is given below. The original article has been corrected.

Publisher's Note Springer Nature remains neutral with regard to jurisdictional claims in published maps and institutional affiliations.

The original article can be found online at https://doi.org/10.1007/ s42398-021-00168-8.

María Fernanda Cerdá

fcerda@fcien.edu.uy

1 Sección Bioquímica, Facultad de Ciencias, Universidad de la República, Iguá 4225, 11400 Montevideo, Uruguay

2 Laboratorio de Biomateriales, Facultad de Ciencias,

Universidad de la República, Iguá 4225, 11400 Montevideo,

Uruguay 
Fig. 3 Photocurrent densityvoltage curves for the DSSC under 1 sun, 1.5 AM irradiation. a Black line $-0.20 \mathrm{~g} \mathrm{~L}^{-1}$ F-violacein; red line

$-0.20 \mathrm{~g} \mathrm{~L}^{-1} \mathrm{NF}$-violacein and blue line $-0.20 \mathrm{~g} \mathrm{~L}^{-1} \mathrm{~F}$-violacein with NP100. b Black line $-0.80 \mathrm{~g} \mathrm{~L}^{-1} \mathrm{~F}$-violacein and blue line $-0.80 \mathrm{~g} \mathrm{~L}^{-1}$ F-violacein with NP100

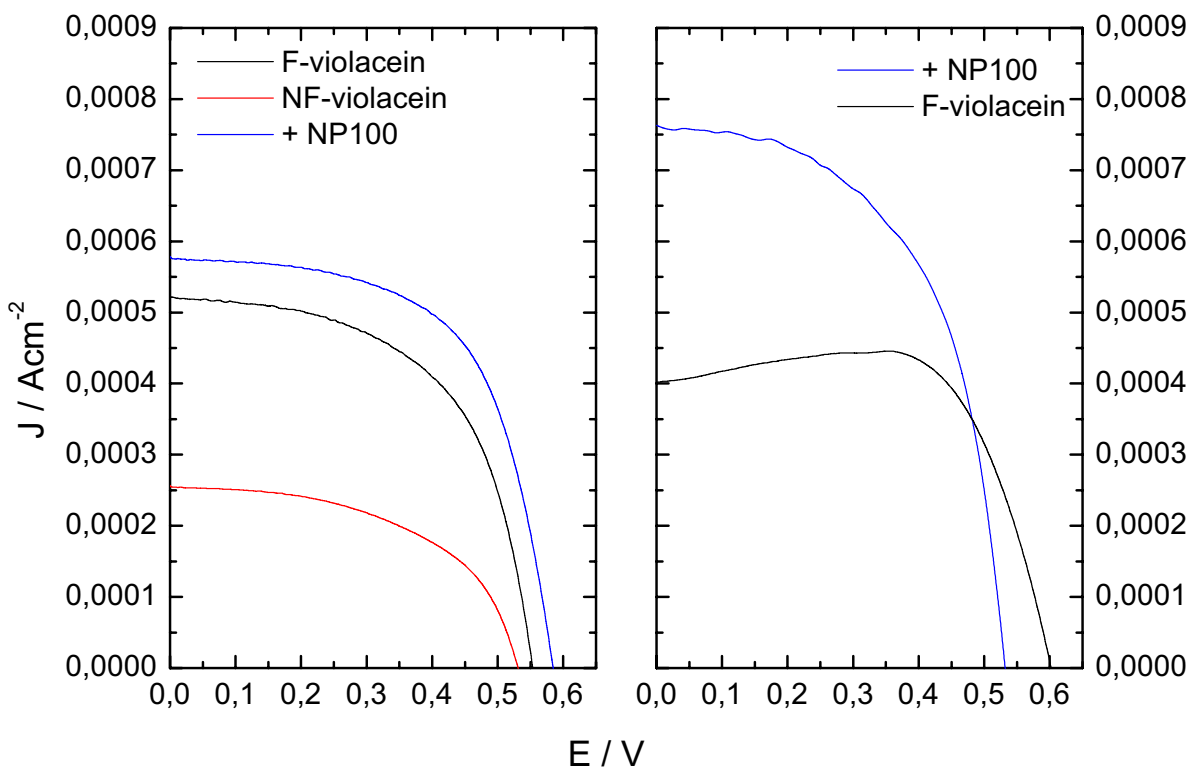

